\title{
Hubungan Kampanye Vaksinasi dengan Sikap Followers untuk Divaksin
}

\author{
Abdullah Mufty Machmud*, Ani Yuningsih \\ Prodi Public Relation, Fakultas Ilmu Komunikasi, Universitas Islam \\ Bandung, Indonesia. \\ *ammachmud@gmail.com,yuningsihani@yahoo.com
}

\begin{abstract}
Recorded cases of Covid-19 in Indonesia reached 1.6 million (26/04/2021). With the outbreak and the dangerous characteristics of this virus, the Indonesian government has focused on handling the virus as a priority, and efforts to prevent its spread continue to be carried out. One of the programs is a vaccination program for all people in Indonesia. Until now, the vaccination program is still ongoing, and the vaccination program is planned to be completed in March 2022. However, several obstacles occur in expanding the vaccination program to the community, one of which is the reluctance to be vaccinated by individuals for various reasons. In this study, we will discuss the relationship of the campaign carried out by the Indonesian Ministry of Health on Instagram to its followers in relation to attitudes to vaccines. This quantitative study aims to determine how big the relationship between vaccination campaign activities and the attitude of followers to be vaccinated. This study uses the theory of Diffusion of Innovations in guiding the implementation of campaign activities that emphasize campaign actors, message content, and the structure of campaign messages with the attitude of followers to be vaccinated and which will be discussed in the form of attitudes from cognitive, affective, conative aspects. The sample to be studied is 100 active Instagram followers with multistage random sampling technique. The result in this research that there's a correlation between vaccination's campaign with followers's attitude that lead will of getting vaccination.
\end{abstract}

Keywords: Covid-19, Campaign, Attitude, Vaccination

Abstrak. Tercatat kasus Covid-19 di Indonesia mencapai 1.6 juta (26/04/2021). Dengan adanya wabah dan bahayanya karakteristik virus ini, pemerintah Indonesia memfokuskan penanganan virus menjadi sebuah prioritas, upaya pencegahan penyebaranpun terus dilakukan. salah satunya program ialah program vaksinasi untuk seluruh masyarakat di Indonesia. Hingga kini program vaksinasi masih terus berlanjut, dan rencananya program vaksinasi akan selesai pada Maret 2022. Namun beberapa kendala terjadi dalam memperluas program vaksinasi ke masyarakat, salah satunya ialah rasa enggan untuk divaksin yang dimiliki oleh individu dengan berbagai alasan yang dimiliki. Di dalam penelitian ini, akan dibahas tentang hubungan daripada kampanye yang dilakukan oleh kementerian kesehatan RI di Instagram terhadap followersnya terkait dengan sikap untuk vaksin. Penelitian kuantitatif ini bertujuan untuk mengetahui seberapa besar hubungan kegiatan kampanye vaksinasi dengan sikap followers untuk divaksin. Penelitian ini menggunakan teori Diffusi Inovasi dalam memandu penyelenggaraan kegiatan kampanye yang ditekankan pada aktor kampanye, isi pesan, dan struktur pesan kampanye dengan sikap followers untuk divaksin dan yang akan dibahas berupa sikap dari aspek kognitif, afektif, konatif. Sampel yang akan diteliti ialah followers aktif Instagram sebanyak 100 orang dengan teknik multistage random sampling. Hasil penelitian ini menunjukkan bahwa adanya hubungan kampanye vaksinasi kemenkes RI di Instagram dengan sikap followers untuk divaksin.

Kata Kunci: Covid-19, Kampanye, Sikap, Vaksinasi. 


\section{A. Pendahuluan}

Diakhir penghujung Tahun 2019 silam. Bumi kita, digemparkan dengan sebuah virus baru yang mulai menyebar kesegala penghujung bentala. Virus ini menjadi sebuah wabah yang tingkat penyebarannya sangat cepat dan masif ke setiap Negara di Dunia. Virus ini dijuluki sebagai Covid-19 (CoronaVirus Disease-2019).

Berdasarkan data yang diambil dari Worldmeters, hingga Senin (26/04/2021. pk: 08:00 WIB) total kasus Covid-19 yang terjadi diberbagai belahan Dunia yang sudah terkonfirmasi, ada sebanyak 147.780 .699 (147 juta jiwa) kasus, dengan jumlah 125.361 .928 (125 juta) jiwa yang sembuh dan 3.122.427 jiwa meninggal Dunia, dikarenakan virus tersebut. Kasus positif Covid-19 yang tertinggi di Dunia, tercatat menimpa Negeri Adidaya yakni Amerika Serikat, terhitung sebanyak 32.824.389 (32 juta), dengan total kesembuhan 25 juta dan 586.152 meninggal Dunia (26/04/2021). Di Indonesia sendiri, virus Covid-19 ini mulai mewabah menyebar ke segala wilayah.

Sehingga pada Senin (26/04/2021) tercatat total kasus Covid-19 ini mencapai lebih dari 1.6 juta kasus di Bumi pertiwi, dan adanya wabah tersebut dan dengan bahayanya karakteristik virus ini yang memang dengan mudahnya dapat menyebar, pemerintah Indonesia memfokuskan penangan urusan virus tersebut sebagai sebuah prioritas.

Upaya pencegahan demi meminimalisir penyebaran virus ini terus diupayakan, salah satu upayanya ialah dengan melakukan vaksinasi masal untuk seluruh masyarakat di Indonesia. Program vaksinasi merupakan salah satu jalan yang diambil oleh pemerintah guna terciptanya tujuan seperti yang diharapkan seperti di atas. Vaksin merupakan virus atau mikro organisme yang dimasukan ke dalam tubuh manusia, untuk menghasilkan kekebalan tubuh terhadap penyakit tertentu.

Program vaksinasi dimulai oleh pemerintah pada Rabu (13/01/2021) di Istana Negara, dan rencananya program vaksinasi ini akan selesai pada penghujung Maret 2022. Sesuai rencana seperti yang sudah dikatakan di atas, program tersebut akan selesai apabila tidak terjadi kendala dalam program vaksinasi, tapi pada kenyataannya terdapat beberapa kendala dimana masyarakat enggan untuk melakukan vaksinasi dengan berbagai alasan yang dimiliki, ini akan menjadi salah satu hambatan yang terjadi dalam penyebarluasan program vaksinasi. Salah satu hal yang dilakukan pemerintah guna menanggulangi hambatan tersebut ialah dengan melaksanakan program kampanye vaksinasi, kampanye bertujuan untuk memberikan sebuah dampak perubahan sesuai dengan apa yang pengkampanye inginkan, dan keinginan tersebut ialah agar masyarakat berkeinginan untuk melakukan vaksinasi.

Kementerian Kesehatan Republik Indonesia yang sejatinya memiliki kredibilitas sebagai ujung tombak program vaksinasi inipun melakukan kegiatan kampanye, salah satunya ialah dengan memanfaatkan platform Instagramnya @ kemenkes_ri dalam menyebarluaskan informasi terkait vaksinasi guna mempersuasi khalayak agar berkeinginan untuk divaksin.

Instagram menjadi salah satu media sosial dengan persentase pengguna yang tinggi di Indonesia yang mencapai 79\% dengan rentan usia penggunanya 16 hingga 64 Tahun, dan selang 7 (Tujuh) bulan virus ini dipublikasi di Indonesia beberapa platform seperti Whatsapp dan Instagram mengalami kenaikan sebanyak $40 \%$ dalam penggunaanya. Ini menjadi salah satu hal yang dimanfaatkan oleh pemerintah guna menyebarluaskan infomasi dan mempersuasi khalayak lewat media sosial tersebut.

Selain daripada popularitas Instagram tersebut, fitur-fitur yang dapat digunakan dalam Instagram yang memudahkan penggunanya dalam memberikan informasi secara efektif seperti fitur unggahan foto maupun vidio, comment, like, share, IGTV, Instagram story, direct message serta mudahnya mencari informasi-informasi yang diinginkan dengan,fitur search, hashtag serta kemudahan melacak identitas pengguna yang melakukan interaksi baik dari fitur chatting maupun like,share serta views.

Penelitian ini dilakukan guna mencari tahu hubungan antara kampanye dengan sikap khalayak yang terterpa kegiatan kampanye, berdasarkan masalah di atas, tentang bagaimana masyarakat Indonesia bersikap maka sekiranya perlu dilakukan beberapa hal dalam rangka meningkatkan pengetahuan, perasaan serta perilaku daripada masyarakat agar nantinya dapat mengikuti program vaksinasi serta mendukung program tersebut. 
Berdasarkan hal tersebut, penulis melakukan penelitian dengan judul Hubungan Kampanye Vaksinasi dengan Sikap Followers Untuk Divaksin dengan tujuan masalah sebagai berikut sebagai berikut

1. Untuk mengetahui hubungan antara pelaku kampanye dengan aspek kognitif followers untuk divaksin?

2. Untuk mengetahui hubungan antara pelaku kampanye dengan aspek afektif followers untuk divaksin?

3. Untuk mengetahui hubungan antara pelaku kampanye dengan aspek konatif followers untuk divaksin?

4. Untuk mengetahui hubungan antara pesan kampanye dengan aspek kognitif followers untuk divaksin?

5. Untuk mengetahui hubungan antara pesan kampanye dengan aspek afektif folowers untuk divaksin?

6. Untuk mengetahui hubungan antara pesan kampanye dengan aspek konatif followers untuk divaksin?

\section{B. Metodologi Penelitian}

Penelitian ini termasuk ke dalam jenis kuantitatif dengan menggunakan metode hubungan atau korelasional, dimana metode penelitian ini meneliti "Hubungan diantara variabel variabel yang diteliti, tujuan dari pada penelitian korelasional ini ialah meneliti tentang sejauh mana variasi dalam suatu faktor yang berkaitan dengan variasi pada faktor lainnya (Rakhmat, 2014: 27).

Di lihat dari banyaknya variabel yang dihubungkan, metode penelitian korelasional ini dibagi menjadi dua jenis yakni, simple correlation (korelasi sederhana) yang hanya menghubungkan dua variabel, dan jenis satunya lagi ialah multiple correlation (korelasi ganda) yang menghubungkan lebih dari dua variabel (Rakhmat, 2014: 27). Melihat dari jumlah variabel dan pengertian tersebut, penelitian ini termasuk ke dalam simple correlation (korelasi sederhana) penelitian, karena penelitian ini ingin mengkaji hubungan diantara 2 (dua) variabel yakni kampanye sebagai variabel yang memberikan pengaruh (X) dan sikap sebagai variabel yang terikat (Y).

Metode korelasional ini digunakan lantaran peneliti ingin mendapatkan hasil dan mengetahui seberapa besar hubungan antara kegiatan kampanye vaksinasi dengan sikap followers untuk divaksin.

\section{Hasil Penelitian dan Pembahasan}

Pada penelitian ini peneliti menggunakan analisa data dengan Koefisien Korelasi Rank Spearman digunakan untuk mencari hubungan kampanye vaksinasi dengan sikap followers untuk divaksin atau menguji signifikansi hipotesis bila masing-masing variabel yang dihubungkan berbentuk ordinal.

Tabel 1. Hubungan Antara Pelaku Kampanye dengan Aspek Kognitif $\left(\mathrm{X}_{1}-\mathrm{Y}_{1}\right)$

\begin{tabular}{ccccccc}
\hline Variabel & Rs & $\begin{array}{c}\text { Kekuatan } \\
\text { Hubungan }\end{array}$ & A & Sig & Keterangan & Keterangan \\
\hline $\begin{array}{c}\text { Pelaku kampanye } \\
\text { dengan aspek } \\
\text { kognitif }\end{array}$ & 0,679 & Kuat & 0,05 & 0,000 & $\mathrm{H}_{0}$ ditolak & Signifikan \\
\hline
\end{tabular}

Berdasarkan tabel 2 dapat diketahui bahwa nilai koefisien korelasi antara pelaku kampanye dengan aspek kognitif adalah sebesar 0,679. Nilai koefisien korelasi tersebut termasuk dalam kategori hubungan yang kuat (Interval 0,600 - 0,799) dan untuk pengujian signifikansi diperoleh hasil yakni sig $<0,05$ maka $\mathrm{H}_{0}$ ditolak, yang artinya terdapat hubungan positif yang signifikan antara pelaku kampanye dengan aspek kognitif. 
Tabel 2. Hubungan Antara Pelaku Kampanye dengan Aspek Afektif $\left(\mathrm{X}_{\left.1-\mathrm{Y}_{2}\right)}\right.$

\begin{tabular}{ccccccc}
\hline Variabel & Rs & $\begin{array}{c}\text { Kekuatan } \\
\text { Hubungan }\end{array}$ & A & Sig & Keterangan & Keterangan \\
\hline $\begin{array}{c}\text { Pelaku kampanye dengan } \\
\text { aspek afektif }\end{array}$ & 0,588 & Cukup Kuat & 0,05 & 0,000 & $\mathrm{H}_{0}$ ditolak & Signifikan \\
\hline
\end{tabular}

Berdasarkan tabel 2 dapat diketahui bahwa nilai koefisien korelasi antara pelaku kampanye dengan aspek afektif adalah sebesar 0,588. Nilai koefisien korelasi tersebut termasuk dalam kategori hubungan yang cukup kuat (Interval 0,400 - 0,599) dan untuk pengujian

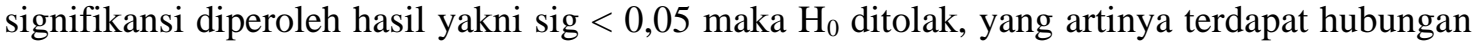
positif yang signifikan antara pelaku kampanye dengan aspek afektif.

Tabel 3. Hubungan Antara Pelaku Kampanye dengan Aspek Konatif $\left(\mathrm{X}_{1}-\mathrm{Y}_{3}\right)$

\begin{tabular}{ccccccc}
\hline Variabel & Rs & $\begin{array}{c}\text { Kekuatan } \\
\text { Hubungan }\end{array}$ & A & Sig & Keterangan & Keterangan \\
\hline $\begin{array}{c}\text { Pelaku kampanye dengan } \\
\text { aspek konatif }\end{array}$ & 0,456 & Cukup Kuat & 0,05 & 0,000 & $\mathrm{H}_{0}$ ditolak & Signifikan \\
\hline
\end{tabular}

Berdasarkan tabel 3 dapat diketahui bahwa nilai koefisien korelasi antara pelaku kampanye dengan aspek konatif sebesar 0,456. Nilai koefisien korelasi tersebut termasuk dalam kategori hubungan yang cukup kuat (Interval 0,400-0,599) dan untuk pengujian signifikansi diperoleh hasil yakni sig $<0,05$ maka $\mathrm{H}_{0}$ ditolak, yang artinya terdapat hubungan positif yang signifikan antara pelaku kampanye dengan aspek konatif.

Tabel 4. Hubungan Antara Pesan Kampanye dengan Aspek Kognitif $\left(\mathrm{X}_{2}-\mathrm{Y}_{1}\right)$

\begin{tabular}{ccccccc}
\hline Variabel & Rs & $\begin{array}{c}\text { Kekuatan } \\
\text { Hubungan }\end{array}$ & A & Sig & Keterangan & Keterangan \\
\hline $\begin{array}{c}\text { Pesan kampanye dengan } \\
\text { aspek kognitif }\end{array}$ & 0,568 & Cukup Kuat & 0,05 & 0,000 & $\mathrm{H}_{0}$ ditolak & Signifikan \\
\hline
\end{tabular}

Berdasarkan tabel 4 dapat diketahui bahwa nilai koefisien korelasi pesan kampanye dengan aspek kognitif adalah sebesar 0,568. Nilai koefisien korelasi tersebut termasuk dalam kategori hubungan yang cukup kuat (Interval 0,400 - 0,599) dan untuk pengujian signifikansi diperoleh hasil yakni sig $<0,05$ maka $\mathrm{H}_{0}$ ditolak, yang artinya terdapat hubungan positif yang signifikan antara pesan kampanye dengan aspek kognitif. 
Tabel 5. Hubungan Antara Pesan Kampanye dengan Aspek Afektif $\left(\mathrm{X}_{2}-\mathrm{Y}_{2}\right)$

\begin{tabular}{ccccccc}
\hline Variabel & Rs & $\begin{array}{c}\text { Kekuatan } \\
\text { Hubungan }\end{array}$ & A & Sig & Keterangan & Keterangan \\
\hline $\begin{array}{c}\text { Pesan kampanye dengan } \\
\text { aspek afektif }\end{array}$ & 0,666 & Kuat & 0,05 & 0,000 & $\mathrm{H}_{0}$ ditolak & Signifikan \\
\hline
\end{tabular}

Berdasarkan tabel 5 dapat diketahui bahwa nilai koefisien korelasi pesan kampanye dengan aspek kognitif adalah sebesar 0,666. Nilai koefisien korelasi tersebut termasuk dalam kategori hubungan yang kuat (Interval 0,600 - 0,799) dan untuk pengujian signifikansi diperoleh hasil yakni sig $<0,05$ maka $\mathrm{H}_{0}$ ditolak, yang artinya terdapat hubungan positif yang signifikan antara pesan kampanye dengan aspek afektif.

Tabel 6. Hubungan Antara Pesan Kampanye dengan Aspek Konatif $\left(\mathrm{X}_{2}-\mathrm{Y}_{3}\right)$

\begin{tabular}{ccccccc}
\hline Variabel & Rs & $\begin{array}{c}\text { Kekuatan } \\
\text { Hubungan }\end{array}$ & A & Sig & Keterangan & Keterangan \\
\hline $\begin{array}{c}\text { Pesan kampanye dengan } \\
\text { aspek konatif }\end{array}$ & 0,642 & Kuat & 0,05 & 0,000 & $\mathrm{H}_{0}$ ditolak & Signifikan \\
\hline
\end{tabular}

Berdasarkan tabel 6 dapat diketahui bahwa nilai koefisien korelasi pesan kampanye dengan aspek kognitif adalah sebesar 0,642. Nilai koefisien korelasi tersebut termasuk dalam kategori hubungan yang kuat (Interval 0,600 - 0,799) dan untuk pengujian signifikansi diperoleh hasil yakni sig $<0,05$ maka $\mathrm{H}_{0}$ ditolak, yang artinya terdapat hubungan positif yang signifikan antara pesan kampanye dengan aspek konatif.

\section{Kesimpulan}

Berdasarkan hasil pengumpulan data, maka diperoleh kesimpulan bahwa variabel X kampanye vaksinasi memiliki hubungan variabel $\mathrm{Y}$ yakni sikap followers untuk divaksin dengan nilai korelasi yang memiliki hubungan yang kuat. Oleh karenanya kampanye vaksinasi memiliki pengaruh tentang bagaimana pelaku dan pesan kampanye kepada followers aktif di Instagram @ kemenkes_ri. Untuk memperkuat hubungan dari kedua variabel ini, peneliti merumuskan setiap variabel, dari variabel $\mathrm{X}$ (kampanye vaksinasi) diturunkan menjadi pelaku kampanye $\left(\mathrm{X}_{1}\right)$ dan pesan kampanye $\left(\mathrm{X}_{2}\right)$. Sedangkan variabel $\mathrm{Y}$ (sikap followers) diturunkan menjadi aspek kognitif $\left(\mathrm{Y}_{1}\right)$, aspek afektif $\left(\mathrm{Y}_{2}\right)$, aspek konatif $\left(\mathrm{Y}_{3}\right)$. Setiap turunan variabel memiliki keterkaitan hubungannya masing-masing yang dapat dilihat sebagai berikut:

1. Adanya hubungan antara pelaku kampanye vaksinasi dengan aspek kognitif followers aktif di Instagram @kemenkes_ri. Berdasarkan hasil nilai korelasi kedua variabel memiliki kategori hubungan yang kuat. Dan variabel X1 (pelaku kampanye) memiliki nilai item pernyataan dengan kategori baik, sedangkan nilai item pernyataan variabel Y1 (aspek kognitif) memiliki kategori pernyataan yang baik. Berdasarkan hasil pengolahan data tersebut dapat disimpulkan pelaku kampanye vaksinasi dapat berhubungan dengan aspek kognitif followers aktif, pengetahuan serta pemahaman followers menjadi bertambah dan semakin kuat.

2. Adanya hubungan antara pelaku kampanye vaksinasi dengan aspek afektif followers aktif di Instagram @kemenkes_ri. Berdasarkan hasil nilai korelasi kedua variabel memiliki kategori hubungan yang cukup kuat. Dan variabel X1 (pelaku kampanye) memiliki nilai item pernyataan dengan kategori baik, sedangkan nilai item pernyataan 
variabel Y2 (aspek afektif) memiliki kategori pernyataan yang baik. Berdasarkan hasil pengolahan data tersebut dapat disimpulkan pelaku kampanye vaksinasi dapat berhubungan dengan aspek afektif followers aktif, followers aktif menjadi tertarik dan senang dengan program vaksinasi.

3. Adanya hubungan antara pelaku kampanye vaksinasi dengan aspek konatif followers aktif di Instagram @kemenkes_ri. Berdasarkan hasil nilai korelasi kedua variabel memiliki kategori hubungan yang cukup kuat. Dan variabel X1 (pelaku kampanye) memiliki nilai item pernyataan dengan kategori baik, sedangkan nilai item pernyataan variabel Y3 (aspek konatif) memiliki kategori pernyataan yang baik. Berdasarkan hasil pengolahan data tersebut dapat disimpulkan pelaku kampanye vaksinasi dapat berhubungan dengan aspek konatif followers aktif, followers aktif akan mengikuti vaksinasi, menyebarluaskan informasi serta mengajak orang untuk ikut serta dalam kegiatan vaksinasi.

4. Adanya hubungan antara pesan kampanye vaksinasi dengan aspek kognitif followers aktif di Instagram @kemenkes_ri. Berdasarkan hasil nilai korelasi kedua variabel memiliki kategori hubungan yang cukup kuat. Dan variabel X2 (pesan kampanye) memiliki nilai item pernyataan dengan kategori baik, sedangkan nilai item pernyataan variabel Y1 (aspek kognitif) memiliki kategori pernyataan yang baik. Berdasarkan hasil pengolahan data tersebut dapat disimpulkan pesan kampanye vaksinasi dapat berhubungan dengan aspek kognitif followers aktif, dengan adanya pesan kampanye yang dapat membuat pemahaman tentang vaksinasi dengan baik, pengetahuan serta pemahaman followers aktif bertambah

5. Adanya hubungan antara pesan kampanye vaksinasi dengan aspek afektif followers aktif di Instagram @kemenkes_ri. Berdasarkan hasil nilai korelasi kedua variabel memiliki kategori hubungan yang kuat. Dan variabel X2 (pesan kampanye) memiliki nilai item pernyataan dengan kategori baik, sedangkan nilai item pernyataan variabel Y2 (aspek afektif) memiliki kategori pernyataan yang baik. Berdasarkan hasil pengolahan data tersebut dapat disimpulkan pesan kampanye vaksinasi dapat berhubungan dengan aspek afektif followers aktif, dengan adanya pesan kampanye tersebut dapat memberikan efek kepada aspek afektif followers aktif dimana adanya kesenangan dan tertarik untuk mengikuti program vaksinasi.

6. Adanya hubungan antara pesan kampanye vaksinasi dengan aspek afektif followers aktif di Instagram @kemenkes_ri. Berdasarkan hasil nilai korelasi kedua variabel memiliki kategori hubungan yang cukup kuat. Dan variabel X2 (pesan kampanye) memiliki nilai item pernyataan dengan kategori baik, sedangkan nilai item pernyataan variabel Y3 (aspek konatif) memiliki kategori pernyataan yang baik. Berdasarkan hasil pengolahan data tersebut dapat disimpulkan pesan kampanye vaksinasi dapat berhubungan dengan aspek afektif followers aktif, dengan adanya pesan kampanye tersebut dapat memberikan efek kepada aspek konatif followers aktif dimana timbul keinginan untuk mengikuti kegiatan vaksinasi, dan menyebarluaskan informasi serta mengajak orang lain untuk ikut serta dalam program vaksinasi

\section{Acknowledge}

Alhamdulillahirabbil'alamin, puji serta syukur penulis panjatkan kehadirat Allah SWT, yang telah memberikan segalanya, mencurahkan rahmat serta karunia-Nya sehingga penulis dapat menyelesaikan penelitian ini dengan judul "Hubungan Kampanye Vaksinasi dengan Sikap Followers Untuk Divaksin (Studi Korelasi Tentang Hubungan Kampanye Vaksinasi Covid-19 Melalui Akun Instagram @kemenkes_ri dengan Sikap Followers Untuk Divaksin)”. Peneliti berharap hasil dari penelitian ini dapat mampu menjadi masukan dalam melaksanakan kegiatan kampanye, khususnya kegiatan kampanye yang dilakukan di media sosial Instagram. Dimana pada penelitian ini telah dibuktikan bahwa pelaku kampanye dan pesan kampanye cukup memberikan efek kepada sikap followers-nya tentang keinginan untuk divaksin, serta 
| Abdullah Mufty Machmud, et al.

\section{Daftar Pustaka}

[1] Ahmadi, Abu dan Uhbiyati, Nur. 2006. Ilmu Pendidikan, Jakarta: Rineka Cipta

[2] Azwar, Saifuddin.2011. Sikap Manusia: Teori dan Pengukurannya. Yogyakarta: Liberty

[3] Bungin. Burhan. Metodelogi Penelitian Kuantitatif. Jakarta: Kencana

[4] Efendy, Onong Uchjana. 2003. Ilmu, teori dan filsafat komunikasi. Bandung: Citra Aditya Bakti.

[5] Efendy, Onong Uchjana. 2009. Komunikasi teori dan praktek. Bandung: PT Remaja. Rosdakarya.

[6] Gumelar, Gumgum. 2013. Psikologi Komunikasi dan Persuasi. Jakarta: Kademia.

[7] Hasan, Iqbal. 2012. Metode Penelitian dan Aplikasinya. Galia Indonesia. Jakarta.

[8] Maulana, Herdiyan, Gumelar, Gumgum. 2013. Psikologi Komunikasi dan Persuasi. Jakarta: Akademia Permata.

[9] Mulyana, Dedi. 2001. Ilmu komunikasi, Suatu Pengantar. Bandung: Remaja Rosdakarya.

[10] Rakhmat, Jalaludin. 2005. Psikologi Komunikasi Edisi Revisi. Bandung: PT. Remaja Rosdakarya.

[11] Rakhmat, Jalaludin. 2007. Metode Penelitian Komunikasi. Bandung: Remaja Karya.

[12] Rakhmat, Jalaludin. 2012. Metode Penelitian Komunikasi. Bandung: Remaja Karya

[13] Rakhmat, Jalaludin. 2014. Metode Penelitian Komunikasi. Bandung: PT Remaja Rosdakarya.

[14] Ruslan Rosady. 2008. Manajemen Public Relations \& Media Komunikasi. Jakarta: PT Rajagrafindo Persada.

[15] Ruslan Rosady. 2013. Manajemen Public Relations \& Media Komunikasi. Jakarta: PT Rajagrafindo Persada.

[16] Schiffman dan Kanuk. 2008. Perilaku Konsumen. Edisi 7. Jakarta: Indeks.

[17] Sarwono, Sarlito W. \& Eko A. Meinarno. 2009. Psikologi sosial. Jakarta: Penerbit Salemba Humanika.

[18] Sarwono, Sarlito W. 2013. Psikologi Remaja. Jakarta: Rajawali Pers.

[19] Severin, Werner J dan James W. Tankard. 2009. Teori Komunikasi: Sejarah, Metode, dan Terapan di dalam Media Massa. Dialihbahasakan oleh Sugeng Hariyanto. Jakarta: Kencana.

[20] Sugiyono, 2010. Metode Penelitian Kuantitatif, Kualitatif dan R\&D. Bandung: Alfabeta.

[21] Sugiyono, 2011. Metode Penelitian Kuantitatif, Kualitatif dan R\&D. Bandung: Alfabeta.

[22] Sugiyono, 2014. Metode Penelitian Kuantitatif, Kualitatif dan R\&D. Bandung: Alfabeta.

[23] Sujarweni, V. Wiratna. 2014. Metode Penelitian: Lengkap, Praktis, dan Mudah Dipahami. Yogyakarta: Pustaka Baru Press.

[24] Venus, Drs. Antar. 2009. Manajemen Kampanye. Bandung: Simbiosa Rekatama Media. 